\title{
Accelerating action to end child marriage in Bangladesh
}

\author{
Sajeda Amin \\ Population Council \\ Jyotirmoy Saha \\ Population Council \\ Masuma Billah \\ Population Council \\ Nargis Sultana \\ Population Council \\ Eashita Haque \\ Population Council
}

See next page for additional authors

Follow this and additional works at: https://knowledgecommons.popcouncil.org/departments_sbsr-pgy

Part of the Demography, Population, and Ecology Commons, Family, Life Course, and Society Commons, International Public Health Commons, and the Maternal and Child Health Commons How does access to this work benefit you? Let us know!

\section{Recommended Citation}

Amin, Sajeda, Jyotirmoy Saha, Masuma Billah, Nargis Sultana, Eashita Haque, and Surojit Kundu. 2018. "Accelerating action to end child marriage in Bangladesh." New York and Bangladesh: Population Council. 


\section{Authors}

Sajeda Amin, Jyotirmoy Saha, Masuma Billah, Nargis Sultana, Eashita Haque, and Surojit Kundu 

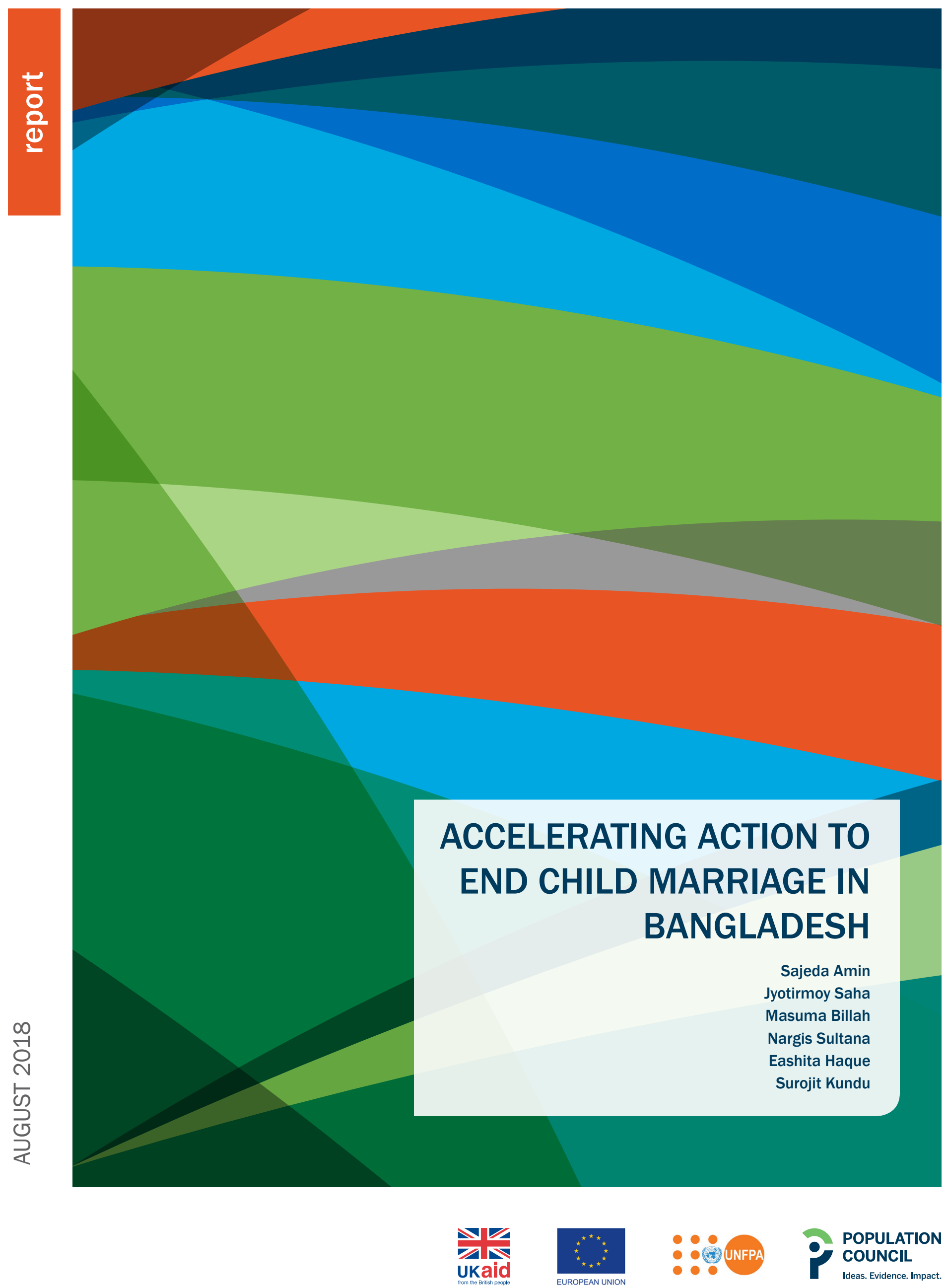


\section{Population
council \\ Ideas. Evidence. Impact.}

The Population Council confronts critical health and development issues-from stopping the spread of HIV to improving reproductive health and ensuring that young people lead full and productive lives. Through biomedical, social science, and public health research in 50 countries, we work with our partners to deliver solutions that lead to more effective policies, programs, and technologies that improve lives around the world. Established in 1952 and headquartered in New York, the Council is a nongovernmental, nonprofit organization governed by an international board of trustees.

\section{Population Council}

1 Dag Hammarskjold Plaza

New York, NY 10017

USA

Tel: +12123390500

Fax: +12127556052

email: pubinfo@popcouncil.org

popcouncil.org

Suggested citation: Amin Sajeda, Saha Jyotirmoy, Billah Masuma, Sultana Nargis, Haque Eashita, and Kundu Surojit. 2018. "Accelerating Action to End Child Marriage in Bangladesh." New York and Bangladesh: Population Council.

(C) 2018 The Population Council, Inc. 


\section{Table of Contents}

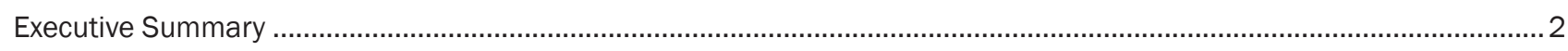

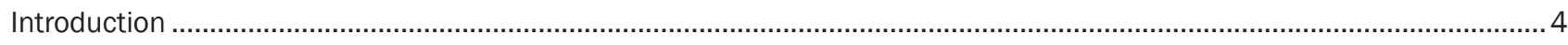

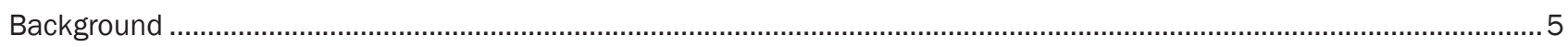

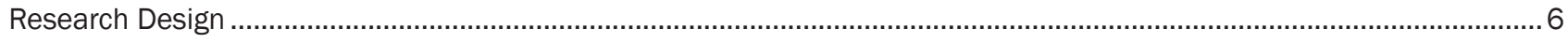

Study Area

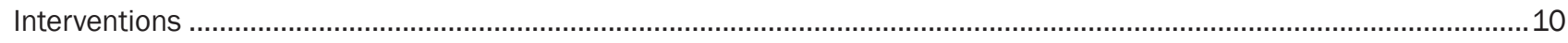

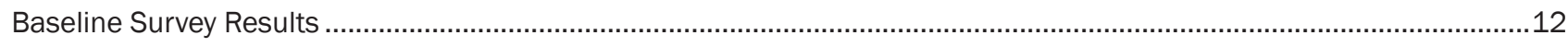

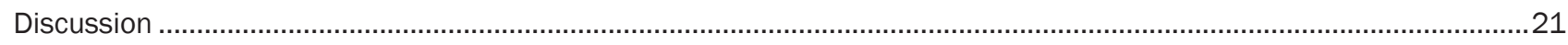

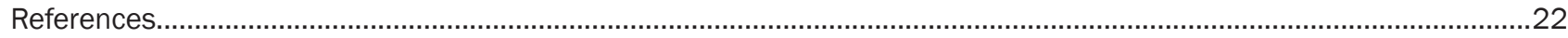




\section{Executive Summary}

\section{Objective}

The objective of the baseline study is to generate a set of indicators against which change can be measured, and to provide specific information about the status of adolescents in the study area in ways that can guide intervention strategies and inform programs and policies. Baseline findings will provide a benchmark against which changes resulting from the intervention may be measured at the endline period and will identify themes in need of further exploration through qualitative research.

\section{Research Design and Study Area}

The research design was developed by the Population Council in cooperation with the United Nations Population Fund (UNFPA), building on the success of BALIKA (Bangladeshi Association for Life Skills, Income, and Knowledge for Adolescents), to identify strategies to scale up skill-building activities along with alternative community participation strategies to ensure long-term sustainability of the program (Amin et al. 2016).

A four-arm cluster randomized trial design was used to evaluate three intervention strategies relative to control areas where no interventions were offered. Arm 1 tests the impact of skill-building alone; Arm 2 tests skill-building plus outreach activities with women; Arm 3 tests skill-building along with outreach activities with men.

Two study districts-Bogura and Jamalpur-were chosen from the list of vulnerable districts identified by the United Nations Development Assistance Framework (UNDAF) upon consultation with UNFPA. Sample size calculations based on a minimal detectable effect size of $20 \%$ decline in marriage under the age of 18 between intervention relative to control arms determined that a total of 96 clusters were needed to detect statistically significant change. At the first stage of randomization, 96 unions from 17 upazillas of Bogura and Jamalpur were randomly selected. One government primary school from each union was randomly selected and later randomly assigned to receive one of the three interventions designed to delay marriage or to serve as a control arm.

\section{Interventions}

The Ministry of Women and Children Affairs (MoWCA) implements all activities conducted by gender promoters in the Kishori Resource Centres. Gender promoters are locally recruited young women who serve as mentors, conduct skills-training sessions, and implement community outreach activities, with technical assistance from the Population Council. At the start of the program, a public invitation was extended to all adolescent girls between the ages of 1[ and 19 in the catchment area (within an easy 2-kilometer walk from the center). The program provides training to two cohorts on a first-come, first-served basis. Participation in the program is entirely voluntary.

Kishori Resource Centres are located at selected primary schools in the community. All girls in interventions arms have the opportunity to receive basic life-skills training, including information about gender rights, sexual and reproductive health and rights (SRHR), and negotiation; critical thinking; decision-making skills; livelihood training in computers; mobile phone applications; and possible income-earning options using mobile-based applications and entrepreneurship.

Community engagement activities involve EIP RQMQ interactions with community members to foster an environment that values girls as assets rather than as liabilities to the household and community.

\section{Baseline Survey Results}

Respondents were randomly selected from 31,822 listed households. The final survey included 2,990 completed interviews out of an attempted 3,741 interviews with adolescents. Out of the 3,741 attempted interviews, 751 (20.1\%) were not conducted mainly because the respondent was unavailable after three household visits (55.1\%), was not within the specified age range upon further age probing $(18.6 \%)$, or refused to participate in the survey (1\%).

There are no significant differences across intervention and control arms in educational outcomes with the exception of a marginally higher (3.6\%) percentage of Arm 3 girls who reported that they had never attended school compared to $2.3 \%$ overall who reported they had never attended school. In terms of levels of education achieved, $11.3 \%$ had a 
primary-level education or less, $12.5 \%$ completed primary schooling only, $57.8 \%$ were in secondary school but had not yet completed secondary education, and $18.4 \%$ reported completing the Secondary School Certificate examination. The average years of schooling completed is 7.5. Marriage is the primary reason for dropping out of school, with $61.1 \%$ reporting that they dropped out because of marriage.

Respondents were more likely to be literate in their native language than in English, which is taught as a second language. In a widely used test of literacy that involves reading two simple sentences, $41.9 \%$ of respondents could read two sentences in English and 87.9\% were able to read two sentences in Bangla, the native language of instruction. Numeracy skills are poorer: $37.5 \%$ completed a subtraction problem correctly, and 5.9\% answered a geometry problem correctly.

Marriage characteristics were similar across study arms, but there were significant differences between districts. Of all marriages, $81.7 \%$ were registered, but the percentage was slightly lower in Bogura (78.7\%) compared to Jamalpur (92.6\%). Overall, respondents in Bogura were more likely to have a voice in decisions about marriage. Asked whether they had agreed to the marriage, $82.4 \%$ of married respondents in Bogura responded in the affirmative compared to Jamalpur (69.6\%). Girls in Bogura were also more likely to report that their parents asked for their consent (76.6\%) compared to girls in Jamalpur (59.3\%). However, there are no strongly significant differences in the proportion of marriages that were reported as "love marriages" (17.2\%). Of all marriages, 58.6\% were reported to involve a dowry payment, with a median reported amount of Taka 50,000 (US\$625).

Overall, $8 \%$ had correct knowledge about the fertile period during the menstrual cycle, 52.3\% knew about antenatal care, and $35.4 \%$ knew about postnatal care. With regard to knowledge of HIV, $65 \%$ had heard of it, and $58 \%$ could correctly cite two or more routes of HIV transmission. Only $8 \%$ knew about sexually transmitted diseases and $18.2 \%$ knew about menstrual regulation as a means of pregnancy termination. Knowledge about family planning was considerably higher, with $66.3 \%$ reporting they knew about family planning and $39.7 \%$ reporting that they knew about menstruation before they first experienced it. Use of sanitary pads to manage menstrual flow was reported by $32 \%$.

Among ever-married respondents, 50\% had experienced a pregnancy and $38.5 \%$ had children, while $67.7 \%$ among those sexually active and not currently pregnant were using contraception.

About $28.5 \%$ of respondents reported that they had ever experienced harassment (tease, annoy, call or tell offensive words, whistle, try to seek attention in any other way) in their home, school, or in the community. Experience of sexual harassment was undifferentiated across arms and significantly higher in Bogura. Overall $4 \%$ of respondents had experienced sexual harassment in school and $4.5 \%$ in the community.

A majority of respondents $(76.8 \%)$ reported that their parents were worried and concerned about their safety and security, $24.5 \%$ reported feeling unsafe walking about in their own locality (significantly higher in Arm 1 at 31.5\%), and only $6.7 \%$ had permission to go out of the house alone after dark.

The overwhelming majority (92.5\%) said they thought girls and women should be engaged in income-generating activities. Only $14.7 \%$ overall had ever worked for money themselves (13\% in Bogura and 18.6\% in Jamalpur). Girls in Jamalpur were also more likely to save (35.3\%) compared to girls in Bogura (16.6\%). The majority of girls reported homebased activities such as tailoring (47.4\%) or weaving/pottery (15.0\%), and $8.4 \%$ were teachers or private tutors. Girls worked about 13 hours per week and earned an average of Taka 1,060 (US\$13).

Overall, the data reveal important contrasts in the social lives of adolescents by marital status, education, and age. This generation of adolescents has benefited from educational opportunities that eluded most of their parents. Although school-going is high, learning achievements remain low, particularly in the acquisition of English language and numeracy skills. Child marriage persists and is associated with high levels of demands for dowry by grooms. Despite the considerable campaigns to raise awareness about child marriage and the negatives of dowry, the practices persist. As a result, the majority of girls marry, become sexually active, and begin childbearing while they are still children. Although knowledge of contraception is high, the practice of effective contraceptive use appears to begin only after a first birth. The characteristics of the sample have some important differences by districts. Child marriage is higher in Bogura and school attendance is lower. Workforce participation is low in both areas, with higher engagement and income observed in Jamalpur. 


\section{Introduction}

Despite considerable social and economic progress in Bangladesh, child marriage remains the norm. The Population Council is partnering with UNFPA and MoWCA to empower girls with gender, life skills, and livelihood skills, and to engage communities to address fundamental normative drivers of child marriage.

Child marriage is widely perceived as an intractable problem that is culturally entrenched and immutable. Bangladesh's high rate of child marriage has multifaceted causes and consequences. Parents of girls are usually motivated to marry their daughters off at early ages because of concerns for the girls' sexual safety and security, the need to conform to traditional societal expectations, and the need to avoid higher costs associated with later marriage and dowry demands that rise with age.

The baseline survey describes the lives of adolescent girls in 96 selected communities in Bogura and Jamalpur districts of northern Bangladesh. Based on interviews with nearly 3,000 respondents between 12 and 19 years of age, the survey describes adolescent girls' lives in terms of marriage, education, work, social life, reproductive health and norms, and attitudes and behaviors regarding sexual and reproductive health, mobility, and autonomy. The purpose of this report is to describe baseline characteristics by district and by the arms in which communities have been assigned. The purpose of assigning communities to study arms is to assess the impact of interventions to build adolescent skills and change community social norms around child marriage using a cluster randomized design that will assess the effectiveness of three different program approaches and contrast them to a set of control villages. 


\section{Background}

Bangladesh ranks among the five countries with the highest rate of child marriage in the world, with more than one in five girls married before the age of 15 and nearly $50 \%$ of women aged 20-24 married by the age of 18 (BBS and UNICEF 2015). Child marriage persists in Bangladesh despite many positive changes experienced by women, including increased access to schooling and workforce participation, improved life expectancy, and declining fertility.

Among underlying factors supporting the practice of marrying girls off soon after puberty are community cultural norms that need to be addressed, namely the economics of dowry and girls' sexual safety. Dowry practices motivate child marriage because later marriage entails higher dowries (White 2017). Concerns about sexual safety are often cited as an additional reason to marry off a daughter because of perceived and real threats, as a preemptive strategy for safeguarding their chastity (PLAN International and Coram International 2015). These correlations suggest that in addition to empowering girls, there may be strategies involving focused engagement of segments of the community that can be effective in addressing the normative drivers of child marriage.

Globally, there is limited evidence to date on effective approaches to delay marriage. A recent systematic review of programs to address child marriage assessed 4,000 studies of which only 11 met the researchers' criteria for rigor and 6 showed positive program impact (Kalamar, Lee-Rife, and Hindin 2016). None of the programs explored skill-building strategies and only one had an explicit community engagement or normative component that worked in combination with conditional cash transfers.

In 2016, the Population Council completed the BALIKA project in three districts in Southern Bangladesh having high rates of child marriage-Khulna, Narail, and Satkhira. An 18-month-long randomized controlled trial was conducted to evaluate the impact of community-based skill-building interventions on reducing rates of child marriage. The program reduced child marriage in intervention areas by one-third and also had a significant impact on reducing school dropout rates and girls' experience of violence, and improving learning outcomes, values and attitudes about gender equality, and sexual and reproductive health-related knowledge and health-seeking behavior (Amin et al. 2016). Building on BALIKA's success and given the limited evidence on successful scaled-up approaches, we set out to measure the impact of a scale-up of BALIKA where similar skillsbased training sessions are offered by mentors recruited by a government agency responsible for three centers simultaneously, compared to only one in BALIKA. The project also tests alternative approaches to engaging the community and assesses their additional contribution. The impact of the project on key outcomes is assessed using a rigorous experimental design.

\section{Global Program to Accelerate Action to End Child Marriage}

The Accelerating Action to End Child Marriage project is part of the UNFPA-UNICEF Global Program to Accelerate Action to End Child Marriage (GPECM) implemented in 12 high-prevalence and/or high-burden countries including Bangladesh. With the goal of ensuring that girls fully enjoy their childhood free from risk of marriage and experience healthier, safer, and more empowered life transitions, GPECM focuses on building girls' skills and knowledge, engaging community members to promote gender-equitable attitudes, strengthening relevant sectors to deliver quality services, ensuring laws and policies that protect and promote adolescent girls' rights, and generating and using robust data to inform programs and policies relating to adolescent girls.

The project is designed to identify ways to scale up skill-building activities along with alternative community participation strategies to ensure long-term sustainability of the program. The project is a randomized controlled trial where a program was assessed involving more than 13,000 girls aged 10-19 in 72 communities within two districts (Bogura and Jamalpur) of Bangladesh. The aim of the project is to develop and evaluate a skill-building program that is girl-centered, cost effective, sustainable, and community-owned, as well as identify pathways to scale. The research design builds upon the evidence-based BALIKA skill-building interventions by adding and evaluating a new community-engagement component. 


\section{Research Design}

The research design of the Accelerating Action to End Child Marriage in Bangladesh project, which aims to improve the lives of adolescent girls, was developed by the Population Council in cooperation with UNFPA. The project is designed to identify ways to scale up skill-building activities along with alternative community-participation strategies to ensure the long-term sustainability of the program.

\section{The specific objectives of the program are as follows:}

- Evaluate the effectiveness and impact of interventions implemented by MoWCA and developed in partnership with UNFPA (with technical assistance from the Population Council) to delay marriage and empower girls with skills and community support in these settings.

- Build on the qualitative and quantitative evidence base that informs the program at baseline, describes programs as they are implemented, and measures their impact on marriage decisions and timing as well as other aspects of adolescent well-being. Intervening outcomes of interest include women's voice in decisions about marriage, educational participation, livelihoods activities, and use of family planning and reproductive health services.

- Measure the implementation of programs through a monitoring and evaluation platform associated with different programmatic options.

The objective of the baseline study is to generate a set of baseline indicators against which change can be measured, and to provide specific information about the status of adolescents in the study area in ways that can guide intervention strategies and inform programs and policies for adolescents. Baseline findings will provide a benchmark against which changes resulting from the intervention may be measured at the endline period and identify themes in need of further exploration through qualitative research.

\section{The specific questions we seek to address are as follows:}

1. Can a skill-building program implemented by a government agency covering several villages delay marriage relative to control villages without intervention?
2. Are there synergistic effects of making communities safer for girls, reducing child marriage, and reducing violence within marriage?

3. As an add-on component to skill-building programs, what is the contribution of community engagement with groups of adult men and women?

4. If adults in the community are engaged, is it better to enlist the support of women's groups only or is it better to work with men?

5. Are program effects sustained over a two- and four-year period (contingent on funding)?

To rigorously evaluate the impact of the Accelerating Action to End Child Marriage in Bangladesh project and its core components, we used a cluster randomized trial design to evaluate the project's individual components at the community level. Randomized controlled trials are preferred over nonrandomized trials for evaluating the impact of an intervention, because randomization of subjects into treatment and comparison groups reduces selection bias and confounding when variables related to the intervention and outcome are similar across study groups. Utilizing a randomized controlled trial design improves the likelihood that any differences between the groups at endline may be attributable to the program itself.

\section{Sample Size Calculation}

The sample size for the two-level four-arm cluster randomized controlled trial was calculated by comparing statistical power using the proportion of married females aged 15-19 as the population parameter. Data from the 2011 Population and Housing Census were used to obtain estimates of the proportion of females aged 15-19 (Minnesota Population Center 2018) currently married in Nishindara union of Bogura district (33\%) as the lowest possible value and the proportion in Khamarkandi union of Bogura district (61\%) as the highest. On average, $48 \%$ of girls are currently married in our proposed areas and we expect a decrease in child marriage of $20 \%$ (down to $38 \%$ ). We calculated the optimal sample size that would allow adequate statistical power to 
FIGURE 1. A four-arm intervention research design to test the added impact of female and male outreach strategies

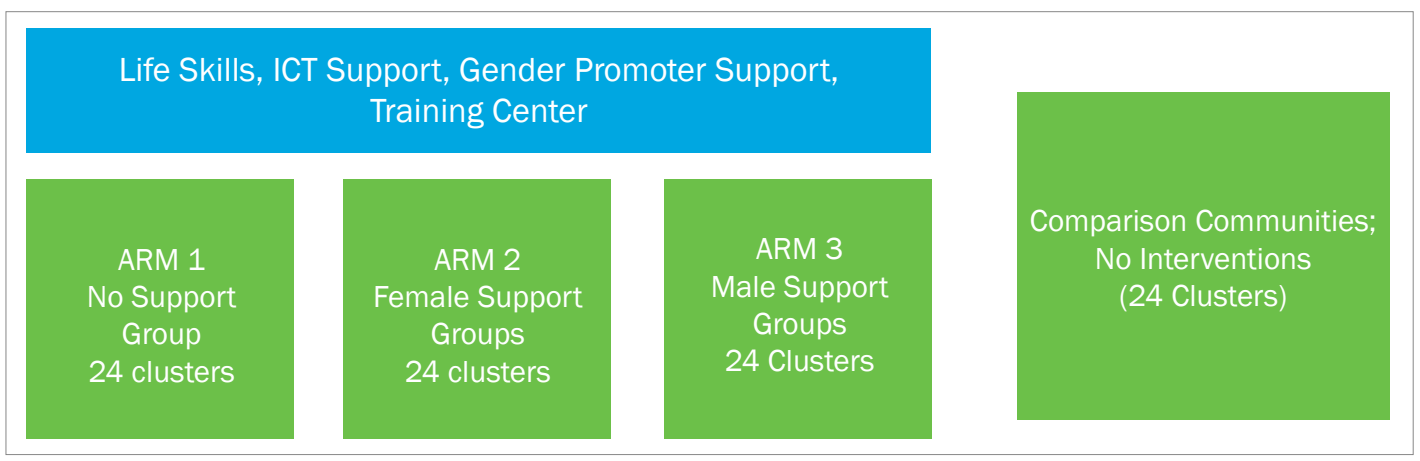

detect an impact within a reasonable timeframe and would be logistically feasible to implement. We assumed between-cluster coefficient of variation $\mathrm{k}=0.17$ and an average cluster size of 30 adolescents per union. Based on these assumptions, calculation of the number of unions per arm was performed by using the following formula (Rutterford, Copas, and Eldridge 2015):

$c=1+\frac{\left(Z_{1-\alpha / 2 \ldots}+Z_{1-\beta}\right)^{2}\left[\frac{P_{1}\left(1-P_{1}\right)}{n}+\frac{P_{2}\left(1-P_{2}\right)}{n}+k^{2}\left(P_{1}^{2}+P_{2}^{2}\right)\right]}{\left(P_{1}-P_{2}\right)^{2}}$

where $c$ is the required number of clusters/unions per arm, $Z x$ is the $x$ 'th percentage point of the standard normal distribution, $\mathrm{P}_{1}-\mathrm{P}_{2}$ represents expected magnitude of the effect of a program or difference between the treatment and control group, $\mathrm{P}_{1}$ is the probability of an event in the control group, $\mathrm{P}_{2}$ is the probability of an event in the treatment group, and $\mathrm{n}$ is the cluster size.

We found that a minimum of 24 unions per arm and a sample of 30 adolescents in each union with 720 respondents per arm is sufficient to measure the impact of the program with $83 \%$ statistical power. Then, we randomly selected 96 unions from 157 available unions (excluding 20 unions from Jamalpur where UNICEF is already implementing similar activities) using the random number generation sampsi command in STATA 13.0. After that, 96 clusters were randomly assigned to one of four possible arms, and 30 adolescents were randomly selected within 2 kilometers of the selected school of each union from the list of adolescents identified in a household enumeration survey. The achieved sample of 2,990 slightly exceeds the targeted sample size of 2,880 girls (30 per union) required to detect a $20 \%$ reduction in child marriage prevalence by the end of the intervention period.

\section{The intervention arms are as follows:}

- $\quad$ Skill-building intervention with no community engagement.

- $\quad$ Skill-building intervention with female community members as supportive allies.

- $\quad$ Skill-building intervention with male community members as supportive allies.

\section{Statistical Method}

In this report, T-tests were performed to observe the difference between individual intervention arm versus control arm and whether indicators were significantly different in two study districts. Tests of statistical significance have been adjusted for cluster effect, determined at $5 \%$ level $(p<0.05)$. 


\section{Study Area}

The two study districts, Bogura and Jamalpur, were chosen

in consultation with UNFPA from UNDAF-designated priority districts.

As shown on the Project Map (opposite page), the study districts are adjacent but separated by a major river. The average community is 10 kilometers away from the upazilla center in Bogura and 13 kilometers away in Jamalpur, with an average commuting time of half an hour. Communities are, on average, 5 kilometers away from the nearest road in Bogura and 3 kilometers away in Jamalpur. Roads are the main access route for $98 \%$ of communities in Bogura and $83 \%$ of communities in Jamalpur. The communities are mostly agriculture-based. Rice, jute, and vegetable production, as well as small-scale poultry rearing and fisheries, dominate the economy. In both districts, home-based enterprise is a common source of income. Bogura and Jamalpur are both known for their quilting (kantha) tradition and distinctive brand of quilt embroidery. This traditional craft has been developed into a cottage industry. Quilting is primarily done by women. Women also work in home-based enterprises such as pottery, cap-making, and broommaking. On average, there are two government primary schools and one secondary school in communities surveyed. There is also an average of one madrasa (Islamic school) in each community. There are, on average, five mosques in each community and a Hindu temple in every three. Presence of institutions such as banks, cultural clubs, and restaurants is rare.

At the first stage of randomization, 96 unions from 17 upazillas of Bogura and Jamalpur were randomly selected. After that, one government primary school from each union was randomly selected and later randomly assigned to receive one of the three interventions designed to delay marriage or to serve as a control arm. 


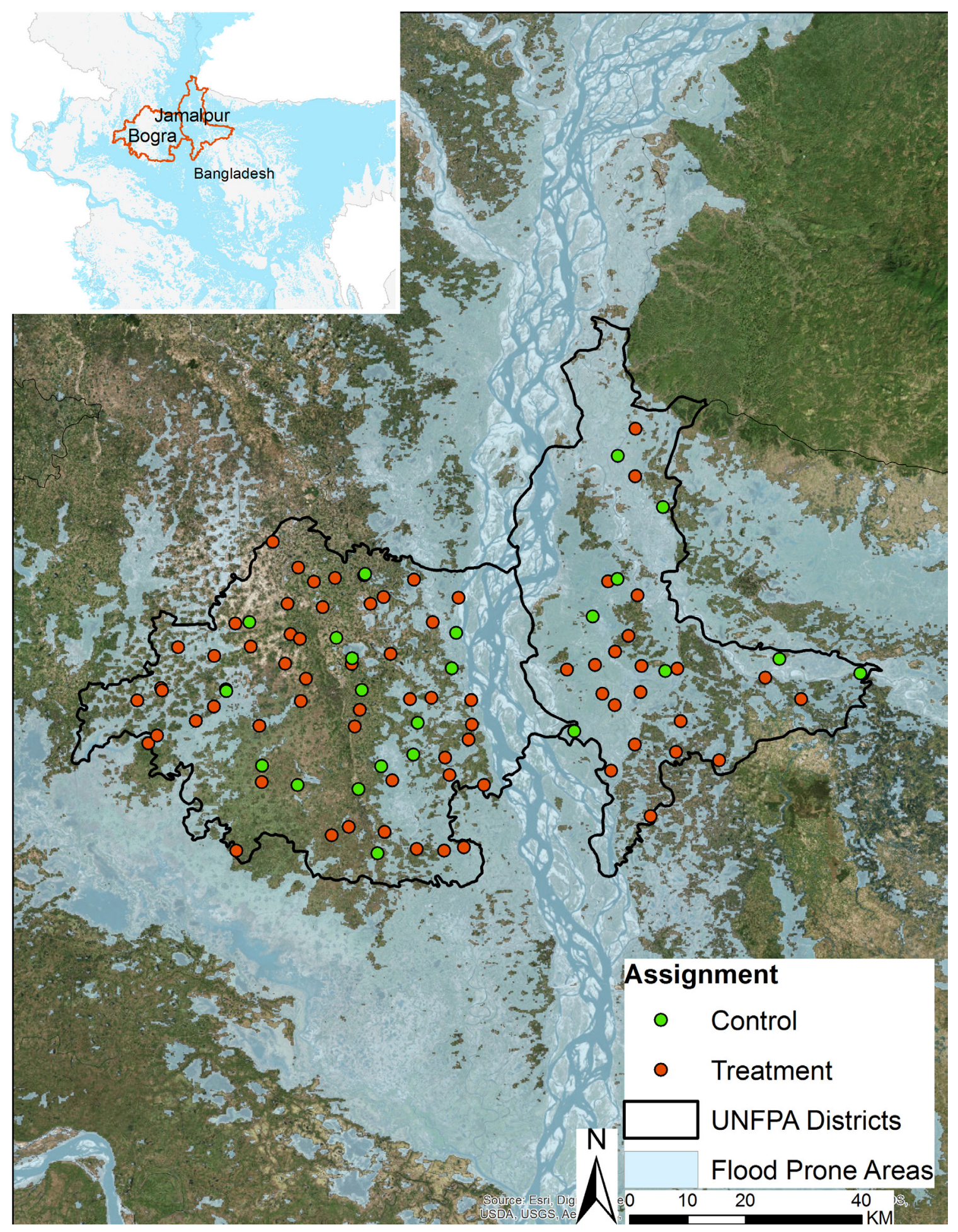




\section{Interventions}

The project reaches two cohorts of girls, each with one-yearlong programs over the course of a two-year intervention period. Over the two years, skill-development programs are implemented in 72 randomly selected communities, and 24 communities serve as controls. MoWCA is implementing all activities in the Kishori Resource Centres with technical assistance from the Population Council.

A trained gender promoter recruited from the locality issues a public invitation to all adolescent girls between the ages of 10 and 19 to join the program in the catchment area (within a 2-kilometer walk to the center) identified by a household listing survey. The program provides training to two cohorts on a first-come, first-served basis. Participation in the program is entirely voluntary.

Kishori Resource Centres are located in the center of communities, at selected primary schools (where available, or any appropriate available infrastructure), to offer safe learning environments where girls receive mentoring and peer support and are offered various types of skills and livelihoods training. Participants in all intervention arms meet weekly for two hours and use computers with digital content to acquire varied skills on gender norms, life skills, and livelihoods. The centers are equipped with a laptop, modem, mouse, and speakers. By the end of each training period, all girls will receive basic life-skills training (information about gender rights, SRHR, and negotiation; critical thinking and decision-making skills); and livelihood-related training (entrepreneurship, and computer- and mobile-phone-based technology training).

All arms will see some initial and limited community-level activities to create a supportive environment for the program. In addition, in the intervention arm that includes community engagement, the program mobilizes support groups among adult men and women. Support-group members are recruited by asking the girls who are members to identify supportive adults from their community. The MoWCA representative reaches out to the identified adults to enlist them as support-group members. All enlisted members are informed that their participation is entirely voluntary. The role of the support group members is to attend monthly group meetings at times agreed upon with the program implementer. These meetings are convened to discuss issues important to the adolescent-skills program and issues regarding the safety and security of girls in the area. The discussions are guided by the gender promoter and use discussion prompts such as flip charts or video documentaries.

Community engagement involves frequent interactions (bimonthly) with community members to foster an environment that values girls as assets rather than as liabilities to their household and community. All three intervention arms include the creation of safe spaces and provide training in basic life skills, gender rights, SRHR, and livelihood skills for adolescent girls. Communities assigned to the control group do not receive a skill-building intervention, community engagement, or placebo exposures.

\section{Household Listing}

We conducted a household listing of approximately 300 households living within a 2-kilometer walk of each randomly selected school. Approximately 31,822 households were counted. A total of 10,034 girls aged 12-19 were listed in 96 unions, with on average 105 adolescent girls aged 12-19 in each union. The definition of a household, based on the Demographic and Health Surveys (DHS), includes that members have the same household head and share the same cooking pot or kitchen (NIPORT, Mitra and Associates, and ICF International 2013). The household listing includes a short survey completed by the head of the household or, if he/she was not available, the spouse of the head of the household or, if the spouse was not available, another adult household member. The household listing included basic demographic information on all members and detailed information on schooling, marital status, age at marriage, and childbearing status of adolescent girls. A filtering question at the beginning of the household listing determined whether the interviewer was to complete the full household roster. The filtering question was, "How many adolescent girls 10-21 years of age live in this household?" Two additional years were included on either end of the age bracket to minimize intentional age misreporting and age heaping. 
The household listing was conducted by a team of male and female interviewers from the local area who were selected based on educational qualifications that required at minimum a bachelor's degree. Listing of households took place just prior to the survey date to minimize nonresponse rates due to relocation of respondents. In case of presence of multiple eligible respondents in the same household, only one respondent was selected randomly for the baseline survey to avoid bias from intra-class correlation. Data were collected using mobile phones and monitored remotely to ensure quality.

\section{Survey Team}

Interviews for the baseline survey were conducted by female interviewers holding at least a bachelor's degree, with overall supervision from Population Council staff from the Dhaka office. Supervisors with considerably more research experience were recruited to oversee interviewers. All interviewers were trained for a period of seven days in April 2017. Training sessions included specific instructions about the survey questionnaire and mobile-based or paperless survey instrument, management of handheld devices, collection of data on the GPS location, and other applications available as needed for the survey. The training also offered more general knowledge about the study area, and about the objectives of the research and ethical issues in conducting research including the informed consent process prescribed by the Population Council's Institutional Review Board.

\section{Development of Data Collection Tools}

Baseline data were collected on Android-based mobile phones utilizing SurveyCTO, a cloud-based data-collection tool that harnesses the flexibility of open data kit (ODK), and integrated monitoring dashboards were developed to visualize data, check irregularities, and monitor the overall progress of the survey. The baseline study tools were pretested in the Population Council's BALIKA study conducted recently in Bangladesh. These tools are culturally appropriate and are based on relevant questions regarding adolescents' knowledge and awareness of reproductive health, gender rights, education skills, and livelihood and life skills imperative for designing sophisticated programs to delay early marriage in Bangladesh. Data were collected in real time with smart phones or tablets that had SurveyCTO preloaded. Spatial coordinates were collected to identify the location of study areas as well as service-delivery points.

\section{Ethical Issues}

The research protocol was approved by the Population Council's Institutional Review Board. Throughout the study, protecting and respecting the confidentiality and privacy of informants is critical. The research teams discussed and developed methods and procedural measures in relation to matters such as data-recording style, personal identifiers, transcription and processing procedures, lifespan of unprocessed data, type and places of storage, and data safety and right of access. All data were kept separate from identifying information, and access to data was strictly limited to the research team. Data were collected only after informed consent was received from each respondent. Guardians' assent and participants' informed consent were obtained for minor unmarried girls (aged 12-17); married minor girls were considered emancipated minors, therefore no assent from the guardians was obtained and married minors were able to consent to their own participation. Written informed consent was obtained from adolescent survey participants 18 years or older. All interviews were conducted in private. Identifying details are not included in the presentation of results. Interviewers were trained extensively on ways of conducting interviews and managing data security during data collection and afterward to ensure confidentiality and anonymity. 


\section{Baseline Survey Results}

The baseline survey was conducted among a representative sample of adolescent girls aged 12-19 in the 96 selected communities from April to May 2017 before any intervention activities were initiated in the study areas. Respondents were randomly selected from 31,822 households listed. Table 1 shows the distribution of the total number of girls aged 10-21 who were enumerated, and the target research sample of 12-19-year-olds by schooling and marital status and study arm.

Table 2 shows sample distribution by district and upazilla. The baseline survey included 2,990 completed interviews. The teams attempted a total of 3,741 interviews with adolescents. Only one adolescent was interviewed per household.

Table 3 shows baseline interviews and number of attempted visits by study arm and district. To interview a sampled adolescent, interviewers made three attempts to contact the selected respondent. Interviewers completed $90 \%$ of interviews on the first visit, $8 \%$ on the second visit, and $2 \%$ on the third visit. At the beginning of the survey, interviewers recorded reason for refusal on the hard copies. Out of 3,741 attempted interviews, there were 751 unsuccessful interviews. The primary reason an interview was not completed was because girls were not present in the household after three tries (55.1\%); the interviewer failed to locate the household, or the girl had left the household (11.1\%); the girl's age was not between 12 and 19 (18.6\%); the girl was visiting relatives or working/studying elsewhere (14.2\%); the girl or guardian refused (1\%).

Table 4 shows background characteristics of adolescents surveyed by intervention arm and district of residence. The characteristics of the sample as a whole are as follows: mean age at interview is 14.9 years, age at marriage among those who are married is 14.8 years, $20.8 \%$ of the sample is married, $81.4 \%$ of the sample is in school, $41.9 \%$ reported that mothers had no education and $41.3 \%$ reported that fathers had no education, $96.3 \%$ are Muslim. The sample is well balanced across arms as judged by these characteristics with no significant difference in all arms except that the average number of siblings reported is significantly lower in intervention Arm 2.

There are, however, significant differences in most of the indicators by district. Jamalpur district has a lower percentage of married respondents and a higher percentage of currently-in-school respondents. Respondents in Jamalpur are more likely to report that their parents had no education suggesting that historically there were fewer educational opportunities in Jamalpur relative to Bogura. The average number of siblings reported is 2.1. ${ }^{1}$ Respondents in Jamalpur reported 2.5 siblings on average compared to 2.0 in Bogura suggesting that fertility change has been more rapid in Bogura relative to Jamalpur. Overall, $65.7 \%$ own a birth

TABLE 1. Household listing sampling frame and target sample of adolescent girls by intervention strategy, schooling status, and marital status

\begin{tabular}{|c|c|c|c|c|c|c|}
\hline Study arm & $\begin{array}{l}\text { Total girls } \\
(10-21)\end{array}$ & $\begin{array}{c}\text { Target research } \\
\text { sample } \\
(12-19)\end{array}$ & $\begin{array}{c}\text { In-school } \\
\text { adolescents } \\
(10-21)\end{array}$ & $\begin{array}{c}\text { In-school } \\
\text { adolescents } \\
(12-19)\end{array}$ & $\begin{array}{c}\text { Married } \\
\text { adolescents } \\
(10-21)\end{array}$ & $\begin{array}{c}\text { Married } \\
\text { adolescents } \\
(12-19)\end{array}$ \\
\hline Intervention 1 & 3,590 & 2,631 & 2,819 & 2,078 & 796 & 557 \\
\hline Intervention 2 & 3,206 & 2,312 & 2,506 & 1,807 & 639 & 456 \\
\hline Intervention 3 & 3,364 & 2,457 & 2,637 & 1,914 & 675 & 497 \\
\hline Control & 3,531 & 2,634 & 2,730 & 2,054 & 748 & 534 \\
\hline Total & 13,691 & 10,034 & 10,692 & 7,853 & 2,858 & 2,044 \\
\hline
\end{tabular}

\footnotetext{
${ }^{1}$ Sibship sizes suggest that the average number of children was 3.1 and consistent with fertility rates expected for this sample of households. The sampling was conditioned upon the presence of at least one adolescent girl in the household.
} 
registration card, with Bogura reporting 69\% and Jamalpur reporting $58.5 \%$ of respondents in possession of a card. Jamalpur residents were also less likely to own assets such as mobile phones and personal computers. Housing quality and ownership of goods was used to construct a wealth index that suggested more households in Jamalpur were in the poorer wealth quintiles.
Table 5 shows a series of schooling-related variables among the adolescents. As with background characteristics, there are no significant differences across intervention and control arms in educational outcomes with the exception of a marginally higher percentage of Arm 3 girls (3.6\%) who reported that they never attended school compared to the control group.

TABLE 2. Household listing sampling frame and target sample of adolescent girls by district and upazilla

\begin{tabular}{|c|c|c|c|c|c|c|c|}
\hline District & $\begin{array}{l}\text { Total number } \\
\text { of house- } \\
\text { holds visited }\end{array}$ & $\begin{array}{l}\text { Household } \\
\text { with at } \\
\text { least one } \\
\text { adolescent } \\
(12-19)\end{array}$ & $\begin{array}{l}\text { Household } \\
\text { with at } \\
\text { least one } \\
\text { adolescent } \\
(10-21)\end{array}$ & $\begin{array}{c}\text { Total } \\
\text { number of } \\
\text { adolescents } \\
\text { listed in } \\
\text { household } \\
\text { survey } \\
(10-21)\end{array}$ & $\begin{array}{c}\text { Total } \\
\text { number of } \\
\text { adolescents } \\
\text { listed in } \\
\text { household } \\
\text { survey } \\
(12-19)(1)\end{array}$ & $\begin{array}{c}\text { Total } \\
\text { number of } \\
\text { respondents } \\
\text { at baseline } \\
\text { survey (2) }\end{array}$ & $\begin{array}{c}\% \text { (column 2) } \\
\text { column 1) }\end{array}$ \\
\hline Bogura & 22,557 & 6,122 & 7,981 & 8,899 & 6,636 & 2,050 & \\
\hline Adamdhighi & 903 & 222 & 292 & 330 & 245 & 91 & 37.1 \\
\hline Bogura Sadar & 2,520 & 745 & 940 & 1,057 & 808 & 255 & 31.6 \\
\hline Dhunot & 2,022 & 548 & 703 & 815 & 610 & 188 & 30.8 \\
\hline Dhupchancia & 1,574 & 446 & 605 & 647 & 467 & 154 & 33.0 \\
\hline Gabtoli & 2,006 & 470 & 609 & 682 & 517 & 153 & 29.6 \\
\hline Kahaloo & 2,198 & 581 & 781 & 847 & 619 & 217 & 35.1 \\
\hline Nandigram & 659 & 163 & 225 & 242 & 175 & 62 & 35.4 \\
\hline Sariakandi & 1,536 & 477 & 622 & 713 & 530 & 155 & 29.2 \\
\hline Shajahanpur & 1,289 & 401 & 518 & 593 & 437 & 123 & 28.1 \\
\hline Sherpur & 2,243 & 620 & 804 & 901 & 669 & 224 & 33.5 \\
\hline Shibganj & 4,220 & 1,070 & 1,393 & 1,521 & 1,154 & 303 & 26.3 \\
\hline Sonatala & 1,287 & 379 & 489 & 551 & 405 & 125 & 30.9 \\
\hline Jamalpur & 9,265 & 3,032 & 4,110 & 4,792 & 3,398 & 940 & \\
\hline Bakshiganj & 1,251 & 477 & 645 & 760 & 545 & 127 & 23.3 \\
\hline Jamalpur Sadar & 2,774 & 836 & 1,122 & 1,303 & 937 & 282 & 30.1 \\
\hline Madarganj & 1,205 & 491 & 671 & 790 & 544 & 125 & 23.0 \\
\hline Melendah & 2,557 & 844 & 1,169 & 1,347 & 938 & 250 & 26.7 \\
\hline Sarishabari & 1,478 & 384 & 503 & 592 & 434 & 156 & 35.9 \\
\hline $\mathbf{N}$ & 31,822 & 9,154 & 12,091 & 13,691 & 10,034 & 2,990 & \\
\hline
\end{tabular}

TABLE 3. Baseline interview result and visit number

\begin{tabular}{|lccccccc|}
\hline Visit number & Arm 1 & Arm 2 & Arm 3 & Control & Bogura & Jamalpur & Total \\
\hline One & 87.9 & 90.0 & 92.6 & 90.3 & 93.5 & 83.1 & 90.2 \\
Two & 8.8 & 7.5 & 6.4 & 8.3 & 6.0 & 11.5 & 7.8 \\
Three & 3.3 & 2.5 & 1.0 & 1.3 & 0.5 & 5.4 & 2.0 \\
\hline
\end{tabular}


Overall, only $2.3 \%$ of survey respondents reported that they had never attended school, suggesting that schooling is nearly universal for the current generation of adolescents and children. Comparing this figure to the over $41 \%$ of mothers and fathers who never attended school suggests there has been rapid change within the span of one generation (see Table 4). Among survey respondents, 11.3\% had a primary-level education or less, $12.5 \%$ completed primary schooling only, $57.8 \%$ were in secondary school but had not yet completed secondary education, and $18.4 \%$ reported completing the Secondary School Certificate examination. Average years of schooling completed is 7.5. Marriage is the primary reason for dropping out of school, with $61.1 \%$ reporting they dropped out because of marriage. Other reasons given are financial constraints (28.3\%), parental disapproval (27.2\%), disliking study (18\%), having to complete household chores (16.4\%), and concerns about safety (5.4\%) (see Table 5).

TABLE 4. Baseline socioeconomic and demographic characteristics of survey respondents, by intervention strategy and district

\begin{tabular}{|c|c|c|c|c|c|c|c|c|}
\hline $\begin{array}{l}\text { Background } \\
\text { characteristic }\end{array}$ & Arm 1 & Arm 2 & Arm 3 & Control & Bogura & Jamalpur & Total & $\begin{array}{c}\text { BDHS } \\
\text { household } \\
\text { survey } \\
2014^{\mathrm{a}} \\
\end{array}$ \\
\hline Age (mean) & 15.1 & 14.8 & 15.0 & 14.9 & 14.9 & 14.9 & 14.9 & \\
\hline $\begin{array}{l}\text { Age at marriage } \\
\text { (mean) }\end{array}$ & 14.9 & 14.6 & 14.8 & 14.7 & 14.7 & 15.0 & 14.8 & \\
\hline $\begin{array}{l}\text { Girls } \\
\text { married (\%) }\end{array}$ & 21.7 & 20.4 & 22.2 & 19.0 & $23.8 * * *$ & 14.4 & 20.8 & 48.1 \\
\hline $\begin{array}{l}\text { Girls in school } \\
(\%)\end{array}$ & 82.0 & 80.6 & 80.6 & 82.5 & $78.2 * * *$ & 88.5 & 81.4 & \\
\hline $\begin{array}{l}\text { Mother has no } \\
\text { education (\%) }\end{array}$ & 44.4 & 41.3 & 40.8 & 41.0 & $37.0 * * *$ & 52.6 & 41.9 & \\
\hline $\begin{array}{l}\text { Father has no } \\
\text { education (\%) }\end{array}$ & 43.9 & 39.3 & 39.4 & 42.6 & $37.7 * * *$ & 49.0 & 41.3 & \\
\hline $\begin{array}{l}\text { Religion: } \\
\text { Muslim (\%) }\end{array}$ & 98.0 & 96.7 & 95.2 & 95.4 & 95.6 & 97.9 & 96.3 & \\
\hline $\begin{array}{l}\text { Number of } \\
\text { siblings (mean) }\end{array}$ & 2.2 & $2.0 * * *$ & 2.1 & 2.2 & $2.0 * * *$ & 2.5 & 2.1 & \\
\hline $\begin{array}{l}\text { Had birth regis- } \\
\text { tration card (\%) }\end{array}$ & 63.7 & 68.8 & 64.0 & 66.4 & $69.0 * * *$ & 58.5 & 65.7 & \\
\hline \multicolumn{9}{|c|}{ Ownership of assets } \\
\hline $\begin{array}{l}\text { Mobile } \\
\text { telephone (\%) }\end{array}$ & 23.5 & 21.5 & 26.1 & 23.5 & $25.5 * *$ & 19.7 & 23.6 & 21.2 \\
\hline $\begin{array}{l}\text { Personal } \\
\text { computer (\%) }\end{array}$ & 3.2 & $1.0 * * *$ & 2.0 & 3.1 & 2.7 & 1.4 & 2.3 & \\
\hline \multicolumn{9}{|l|}{ Wealth quintile } \\
\hline Lowest (\%) & 23.3 & 20.6 & 17.8 & 19.2 & 19.3 & 22.4 & 20.2 & \\
\hline Second (\%) & 24.0 & 17.1 & 22.0 & 22.2 & $19.3 * *$ & 25.7 & 21.3 & \\
\hline Middle (\%) & 17.2 & 21.0 & 18.6 & 19.6 & 19.6 & 18.0 & 19.1 & \\
\hline Fourth (\%) & 16.8 & 21.0 & 19.4 & 20.3 & 20.2 & 17.4 & 19.4 & \\
\hline Highest (\%) & 18.7 & 20.4 & 22.2 & 18.7 & 21.7 & 16.4 & 20.0 & \\
\hline $\mathrm{N}$ & 750 & 749 & 747 & 744 & 2,050 & 940 & 2,990 & \\
\hline
\end{tabular}

$* * * p<.001, * * p<.01, * p<.05$

apercentages were calculated from BDHS household survey 2014 by selecting girls aged 12-19 residing in rural areas. 
TABLE 5. Comparison of schooling status and reasons for discontinuation, by study arm, district, and age

\begin{tabular}{|c|c|c|c|c|c|c|c|c|c|c|c|}
\hline Variable & Arm 1 & Arm 2 & Arm 3 & Control & Bogura & $\begin{array}{l}\text { Jamal- } \\
\text { pur }\end{array}$ & $\begin{array}{c}\text { Less } \\
\text { than } 16\end{array}$ & $16-17$ & $18-19$ & Total & $\begin{array}{c}\text { BDHS } \\
\text { house- } \\
\text { hold } \\
\text { survey } \\
2014^{\mathrm{a}}\end{array}$ \\
\hline \multicolumn{12}{|l|}{ Schooling status } \\
\hline $\begin{array}{l}\text { Currently in } \\
\text { school }\end{array}$ & 82.0 & 80.6 & 80.6 & 82.5 & $78.2 * *$ & 88.5 & 93.4 & 70.1 & 50.3 & 81.4 & \\
\hline $\begin{array}{l}\text { Never been to } \\
\text { school }\end{array}$ & 2.1 & 1.9 & $3.6^{*}$ & 1.5 & 2.6 & 1.5 & .6 & 3.5 & 7.2 & 2.3 & 3.4 \\
\hline Out of school & 15.9 & 17.5 & 15.8 & 16.0 & $19.2 * *$ & 10.0 & 6.0 & 26.5 & 42.4 & 16.3 & \\
\hline N & 750 & 749 & 747 & 744 & 2,050 & 940 & 1,829 & 718 & 443 & 2,990 & \\
\hline \multicolumn{12}{|c|}{ Highest degree obtained } \\
\hline $\begin{array}{l}\text { Primary } \\
\text { incomplete/ } \\
\text { Illiterate }\end{array}$ & 10.1 & 11.2 & 11.8 & 12.1 & 11.8 & 10.2 & 10.9 & 9.2 & 16.5 & 11.3 & 20.5 \\
\hline $\begin{array}{l}\text { Primary } \\
\text { complete }\end{array}$ & 11.6 & 13.8 & 12.7 & 11.8 & 13.1 & 11.2 & 17.3 & 4.2 & 6.1 & 12.5 & 15.5 \\
\hline $\begin{array}{l}\text { Incomplete } \\
\text { secondary }\end{array}$ & 56.9 & 59.7 & 57.7 & 56.9 & 57.9 & 57.7 & 70.0 & 45.1 & 27.8 & 57.8 & 48.1 \\
\hline $\begin{array}{l}\text { SSC (Secondary } \\
\text { School Certificate) } \\
\text { or higher }\end{array}$ & 21.3 & 15.4 & 17.8 & 19.2 & 17.3 & 21.0 & 1.8 & 41.5 & 49.7 & 18.4 & 15.9 \\
\hline $\begin{array}{l}\text { Average number } \\
\text { of years in school }\end{array}$ & 7.7 & 7.2 & 7.5 & 7.5 & 7.4 & 7.6 & 6.5 & 8.9 & 9.0 & 7.5 & 6.7 \\
\hline$N$ & 750 & 749 & 747 & 744 & 2,050 & 940 & 1,829 & 718 & 443 & 2,990 & \\
\hline \multicolumn{12}{|c|}{ Reasons for school discontinuation/never attended school ${ }^{b}$} \\
\hline Got married & 61.5 & 60.7 & 65.5 & 56.2 & 64.4 & 47.2 & 43.3 & 67.4 & 64.5 & 61.1 & \\
\hline $\begin{array}{l}\text { Financial } \\
\text { constraints }\end{array}$ & 29.6 & 29.7 & 27.6 & 26.2 & 25.1 & 41.7 & 31.7 & 27.4 & 27.3 & 28.3 & \\
\hline $\begin{array}{l}\text { Parents } \\
\text { disapprove }\end{array}$ & 21.5 & 25.5 & 29.0 & 33.1 & 25.7 & 33.3 & 28.3 & 24.2 & 29.5 & 27.2 & \\
\hline $\begin{array}{l}\text { Respondent does } \\
\text { not like to study }\end{array}$ & 17.0 & 16.6 & 14.5 & 24.6 & 16.6 & 24.1 & 26.7 & 14.0 & 17.3 & 18.0 & \\
\hline $\begin{array}{l}\text { Had household } \\
\text { chores/work }\end{array}$ & 17.0 & 14.5 & 15.9 & 18.5 & 15.7 & 19.4 & 15.0 & 12.6 & 20.9 & 16.4 & \\
\hline $\begin{array}{l}\text { Parents } \\
\text { concerned about } \\
\text { safety }\end{array}$ & 5.9 & 4.1 & 4.1 & 7.7 & 5.6 & 4.6 & 3.3 & 4.7 & 7.3 & 5.4 & \\
\hline $\mathrm{N}$ & 135 & 145 & 145 & 130 & 447 & 108 & 120 & 215 & 220 & 555 & \\
\hline
\end{tabular}

$* * * p<.001, * * p<.01, * p<.05$

apercentages were calculated from BDHS household survey 2014 by selecting girls aged 12-19 residing in rural areas.

${ }^{\mathrm{b}}$ Multiple responses. 
TABLE 6. Comparison of language competency and numeracy skills by study arms (\%)

\begin{tabular}{|c|c|c|c|c|c|c|c|}
\hline Variable & Arm 1 & Arm 2 & Arm 3 & Control & Bogura & Jamalpur & Total \\
\hline \multicolumn{8}{|c|}{ Language competency skills } \\
\hline $\begin{array}{l}\text { Correctly } \\
\text { read two } \\
\text { English } \\
\text { sentences }\end{array}$ & 43.3 & 41.0 & 44.3 & 38.8 & 43.3 & 38.8 & 41.9 \\
\hline $\begin{array}{l}\text { Correctly } \\
\text { read two } \\
\text { Bangla } \\
\text { sentences }\end{array}$ & 88.7 & 87.4 & 88.9 & 86.7 & 88.4 & 86.9 & 87.9 \\
\hline \multicolumn{8}{|c|}{ Numeracy skills } \\
\hline Profit-loss & $10.4 *$ & 17.1 & 15.7 & 17.2 & 14.5 & 16.3 & 15.1 \\
\hline Division & 11.7 & 11.5 & 13.7 & 11.6 & 12.5 & 11.2 & 12.1 \\
\hline $\begin{array}{l}\text { Unit } \\
\text { conversion }\end{array}$ & 9.5 & 13.9 & 9.1 & 12.2 & 11.8 & 9.8 & 11.2 \\
\hline $\begin{array}{l}\text { Fraction } \\
\text { manipulation }\end{array}$ & 5.3 & 3.2 & 8.0 & 4.6 & 5.8 & 4.1 & 5.3 \\
\hline Subtraction & 36.5 & 39.4 & 36.1 & 37.8 & 38.2 & 35.9 & 37.5 \\
\hline Geometry & 4.7 & 6.0 & 7.5 & 5.2 & 6.1 & 5.3 & 5.9 \\
\hline $\mathbf{N}$ & 750 & 749 & 747 & 744 & 2,050 & 940 & 2,990 \\
\hline
\end{tabular}

$* * * p<.001, * * p<.01, * p<.05$

Table 6 shows that overall $41.9 \%$ of respondents could read two sentences in English and 87.9\% were able to read two sentences in Bangla, the native language of instruction. Numeracy skills are poorer, with only $15.1 \%$ able to answer a word problem involving calculating profit and loss; $12.1 \%$ able to manipulate a division problem correctly; $11.2 \%$ able to do a unit conversion problem; 5.3\% answering a fraction manipulation correctly; 37.5\% subtracting correctly; and $5.9 \%$ answering a geometry problem correctly.

The survey included several questions regarding marriage characteristics. The findings from Table 7 show that most of the characteristics were similar across study arms but there were significant differences between districts. Among all marriages $81.7 \%$ were registered overall, but the percentage was lower in Bogura (78.7\%) compared to Jamalpur (92.6\%). Overall $79.6 \%$ of girls reported they had agreed to the marriage and the percentage was higher in Bogura (82.4\%) compared to Jamalpur (69.6\%). Girls in Bogura are also more likely to report that their parents asked for their consent (76.6\%) compared to girls in Jamalpur (59.3\%). There are no significant differences in the proportion of marriages that were reported as "love marriages" (17.2\%) except for intervention Arm 3 where it was 11.4\%. Among all marriages, 58.6\% are reported to involve a dowry payment, with the median amount reported as Taka 50,000 (US\$625).

As shown in Table 8, overall there were no significant differences by intervention arm with regard to sexual and reproductive health knowledge. Overall, $8 \%$ had correct knowledge about the fertile period during the menstrual cycle, 52.3\% knew about antenatal care and 35.4\% about postnatal care. With regard to knowledge about HIV, 65\% had heard about HIV, and 58\% could correctly cite two or more routes of HIV transmission. Only $8 \%$ knew about sexually transmitted infections and $18.2 \%$ about menstrual regulation as a means of pregnancy termination. However, by contrast $66.3 \%$ knew about family planning and $39.7 \%$ knew about menstruation before they first experienced it. To manage menstrual flow, 32\% reported that they used sanitary pads. When asked about whether they had themselves experienced a reproductive health problem, 8.2\% answered in the affirmative. Among them 51.8\% received treatment. Among ever-married respondents 50\% had experienced a pregnancy and $38.5 \%$ had children, while $67.7 \%$ among those sexually active but not currently pregnant were using contraception. On all knowledge and some sexual and 
TABLE 7. Percentage of marriages registered, and dowry payments made by study arm, and according to district

\begin{tabular}{|lccccccc|}
\hline \multicolumn{1}{|c}{ Variable } & Arm 1 & Arm 2 & Arm 3 & Control & Bogura & Jamalpur & Total \\
\hline $\begin{array}{l}\text { Marriage was } \\
\text { registered }\end{array}$ & 89.6 & 73.2 & 80.7 & 83.0 & $78.7 * *$ & 92.6 & 81.7 \\
$\begin{array}{l}\text { Girl agreed to } \\
\text { marry }\end{array}$ & 81.6 & 73.9 & 78.9 & 84.4 & $82.4 * *$ & 69.6 & 79.6 \\
$\begin{array}{l}\text { Parents } \\
\text { asked for }\end{array}$ & & & & & & & \\
$\begin{array}{l}\text { girl's } \\
\text { consent } \\
\text { before } \\
\text { marriage }\end{array}$ & 72.4 & 74.5 & 71.7 & 73.1 & $76.6 * *$ & 59.3 & 72.9 \\
$\begin{array}{l}\text { Love } \\
\text { marriage }\end{array}$ & 23.3 & 13.1 & $11.4 *$ & 21.3 & 16.2 & 20.7 & 17.2 \\
$\begin{array}{l}\text { Dowry } \\
\text { demanded }\end{array}$ & 59.5 & 64.1 & 59.6 & 50.4 & 60.2 & 52.6 & 58.6 \\
$\mathbf{N}$ & 163 & 153 & 166 & 141 & 488 & 135 & 623 \\
$\begin{array}{l}\text { Median } \\
\text { amount of } \\
\text { dowry given } \\
\text { (takas) }\end{array}$ & 60,000 & 50,000 & 50,000 & 60,000 & 55,000 & 50,000 & 50,000 \\
$\mathbf{N}$ & 97 & 98 & 99 & 71 & 294 & 71 & 365 \\
\hline
\end{tabular}

$* * * p<.001, * * p<.01, * p<.05$

reproductive health behavior indicators there are significant differences between Bogura and Jamalpur, with knowledge levels being consistently poor in Bogura relative to Jamalpur.

As Table 9 shows, about 28.5\% reported that they had ever experienced harassment (tease, annoy, call or tell offensive words, whistle, try to seek attention in any other way) either in their home, school, or in the community. Experience of sexual harassment was undifferentiated across arms and significantly higher in Bogura. Overall 4\% of respondents had experienced sexual harassment in school and $4.5 \%$ in the community.

Table 10 shows that $76.8 \%$ of respondents reported that their parents were worried and concerned about their safety and security, $24.5 \%$ reported feeling unsafe walking about in their own locality (significantly higher in Arm 1 at 31.7\%), and only $6.7 \%$ had permission to go out of the house alone after dark.

Table 11 shows, in terms of economic activities there are no differences by arm or district except for the propensity to save which is higher in Jamalpur. Girls in Bogura are less likely to be engaged in economic activities. The overwhelming majority (92.5\%) said they think girls and women should be engaged in income-generating activities. Only $14.7 \%$ overall had ever worked for money themselves (13\% Bogura and $18.6 \%$ Jamalpur). Girls in Jamalpur were also more likely to save (35.3\%) compared to $16.6 \%$ in Bogura. The majority of girls reported home-based activities such as tailoring (47.4\%) or pottery/weaving (15\%); $8.4 \%$ are teachers or private tutors. Girls who worked reported working 13 hours per week on average and earning an average of Taka 1,060 (around US\$13). 
TABLE 8. Adolescents' responses regarding sexual and reproductive health knowledge and practices, by intervention strategy

\begin{tabular}{|c|c|c|c|c|c|c|c|}
\hline Variable & Arm 1 & Arm 2 & Arm 3 & Control & Bogura & Jamalpur & Total \\
\hline \multicolumn{8}{|c|}{ Knowledge about: } \\
\hline $\begin{array}{l}\text { Correct fertile } \\
\text { period }\end{array}$ & 8.7 & 8.3 & 7.0 & 7.8 & $9.3 * * *$ & 5.2 & 8.0 \\
\hline Antenatal care & 57.3 & 52.2 & 49.0 & 50.5 & $45.0 * * *$ & 68.1 & 52.3 \\
\hline Postnatal care & 42.7 & 33.0 & 32.5 & 33.3 & $25.7 * * *$ & 56.6 & 35.4 \\
\hline HIV/AIDS & 66.3 & 60.3 & 66.7 & 65.5 & 64.0 & 66.3 & 64.7 \\
\hline $\begin{array}{l}\text { Two or more } \\
\text { routes of HIV } \\
\text { transmission }\end{array}$ & 60.8 & 53.3 & 60.5 & 56.9 & $56.2^{*}$ & 61.4 & 57.9 \\
\hline $\begin{array}{l}\text { Sexually } \\
\text { transmitted } \\
\text { infections }\end{array}$ & 7.6 & 6.5 & 10.8 & 6.9 & $6.2 * * *$ & 11.7 & 8.0 \\
\hline $\begin{array}{l}\text { Menstrual } \\
\text { regulation }\end{array}$ & 22.9 & 16.7 & 16.9 & 16.4 & $16.3 *$ & 22.3 & 18.2 \\
\hline $\begin{array}{l}\text { Family } \\
\text { planning }\end{array}$ & 70.1 & 63.2 & 65.3 & 66.5 & $63.6 * *$ & 72.1 & 66.3 \\
\hline$N$ & 750 & 749 & 747 & 744 & 2,050 & 940 & 2,990 \\
\hline $\begin{array}{l}\text { Menstruation } \\
\text { before } \\
\text { menarche }\end{array}$ & 38.8 & 43.1 & 40.3 & 36.7 & 41.4 & 36.0 & 39.7 \\
\hline$N$ & 676 & 659 & 670 & 668 & 1,823 & 850 & 2,673 \\
\hline \multicolumn{8}{|c|}{ Sexual and reproductive behaviors } \\
\hline $\begin{array}{l}\text { Has } \\
\text { experienced } \\
\text { any RH-related } \\
\text { problem }\end{array}$ & 7.5 & 7.9 & 9.4 & 8.1 & $9.1^{*}$ & 6.3 & 8.2 \\
\hline $\mathrm{N}$ & 676 & 659 & 670 & 668 & 1,823 & 850 & 2,673 \\
\hline $\begin{array}{l}\text { Received } \\
\text { treatment for } \\
\text { RH-related } \\
\text { problem }\end{array}$ & 57.1 & 42.4 & 54.3 & 53.3 & $56.1 *$ & 37.9 & 51.8 \\
\hline$N$ & 51 & 52 & 63 & 54 & 166 & 54 & 219 \\
\hline $\begin{array}{l}\text { Use sanitary } \\
\text { pad for } \\
\text { managing } \\
\text { menstrual flow }\end{array}$ & 30.4 & 29.8 & 35.2 & 32.5 & $35.5 * *$ & 24.3 & 32.0 \\
\hline $\mathbf{N}$ & 676 & 659 & 670 & 668 & 1,823 & 850 & 2,673 \\
\hline \multicolumn{8}{|c|}{ Among ever-married respondents } \\
\hline Ever pregnant & 52.1 & 43.1 & 53.0 & 51.1 & 49.0 & 53.3 & 49.9 \\
\hline Have children & 40.5 & 33.3 & 39.8 & 40.4 & 38.3 & 39.3 & 38.5 \\
\hline$N$ & 163 & 153 & 166 & 141 & 488 & 135 & 623 \\
\hline $\begin{array}{l}\text { Currently using } \\
\text { any family } \\
\text { planning } \\
\text { method }\end{array}$ & 68.6 & 66.7 & 70.0 & 65.3 & 68.2 & 65.8 & 67.7 \\
\hline$N$ & 140 & 138 & 140 & 121 & 425 & 114 & 539 \\
\hline
\end{tabular}

$* * * p<.001, * * p<.01, * p<.05$ 
TABLE 9. Comparison of experience of physical/psychosocial harassment and sexual harassment by intervention strategy

\begin{tabular}{|lccccccc|}
\hline \multicolumn{1}{|c}{ Variable } & Arm 1 & Arm 2 & Arm 3 & Control & Bogura & Jamalpur & Total \\
\hline $\begin{array}{l}\text { Ever experienced } \\
\text { any type of harass- } \\
\text { ment either at home, } \\
\text { or in school, or in the } \\
\text { community }\end{array}$ & 31.6 & 29.4 & 24.8 & 28.4 & $24.6 * *$ & 37.1 & 28.5 \\
$\begin{array}{l}\text { Ever experienced } \\
\text { harassment at } \\
\text { home }\end{array}$ & 11.5 & 8.1 & 5.6 & 9.9 & $6.0 * * *$ & 14.8 & 8.8 \\
$\begin{array}{l}\text { Ever experienced } \\
\text { harassment in } \\
\text { school }\end{array}$ & 9.5 & 8.8 & 9.7 & 9.3 & $7.9 * * *$ & 12.5 & 9.3 \\
$\begin{array}{l}\text { Ever experienced } \\
\text { harassment in the } \\
\text { community }\end{array}$ & 26.4 & 24.7 & 18.5 & 24.7 & $20.0 * * *$ & 31.4 & 23.6 \\
$\begin{array}{l}\text { Sexual harassment } \\
\text { Ever experienced } \\
\text { sexual harassment } \\
\text { in school }\end{array}$ & 3.3 & 4.2 & 5.0 & 3.7 & $5.0 * *$ & 1.9 & 4.0 \\
$\begin{array}{l}\text { Ever experienced } \\
\text { sexual harassment } \\
\text { in the community }\end{array}$ & 4.3 & 4.5 & 4.3 & 4.8 & 5.5 & 2.3 & 4.5 \\
$\mathbf{N}$ & 750 & 749 & 747 & 744 & 2,050 & 940 & 2,990 \\
\hline
\end{tabular}

$* * * p<.001, * * p<.01, * p<.05$

TABLE 10. Sense of safety and security

\begin{tabular}{|lccccccc|}
\hline \multicolumn{1}{|c}{ Variable } & Arm 1 & Arm 2 & Arm 3 & Control & Bogura & Jamalpur & Total \\
\hline $\begin{array}{l}\text { Parents/ } \\
\text { guardians are } \\
\text { worried about } \\
\text { their daughter's } \\
\text { security }\end{array}$ & 80.1 & 75.4 & 73.1 & 78.4 & 72.8 & 85.3 & 76.8 \\
$\begin{array}{l}\text { Feel unsafe or } \\
\text { fearful walking } \\
\text { and roaming } \\
\text { around locality }\end{array}$ & $31.7^{*}$ & 19.4 & 26.2 & 20.7 & 21.0 & 32.1 & 24.5 \\
$\begin{array}{l}\text { Allowed outside } \\
\text { after sunset }\end{array}$ & 7.7 & 6.3 & 6.7 & 6.0 & 7.4 & 5.2 & 6.7 \\
$\mathbf{N}$ & 750 & 749 & 747 & 744 & 2,050 & 940 & 2,990 \\
\hline
\end{tabular}

$* * * p<.001, * * p<.01, * p<.05$ 
TABLE 11. Key livelihoods indicators, by district and intervention strategy

\begin{tabular}{|c|c|c|c|c|c|c|c|c|c|c|}
\hline Variable & Arm 1 & Arm 2 & Arm 3 & Control & Bogura & $\begin{array}{c}\text { Jamal- } \\
\text { pur }\end{array}$ & $\begin{array}{c}\text { In } \\
\text { School }\end{array}$ & $\begin{array}{l}\text { Out-of- } \\
\text { School }\end{array}$ & Total & $\begin{array}{c}\text { BDHS } \\
\text { house- } \\
\text { hold } \\
\text { survey } \\
2014^{\text {a }}\end{array}$ \\
\hline $\begin{array}{l}\text { Do you think a girl/woman } \\
\text { should be involved in } \\
\text { income-generating activities? } \\
\text { (\%) }\end{array}$ & 94.1 & 90.3 & 92.4 & 93.3 & 91.7 & 94.4 & 92.2 & 93.7 & 92.5 & \\
\hline Ever worked to earn money (\%) & 17.2 & 10.5 & 18.5 & 12.8 & 13.0 & 18.6 & 13.6 & 19.6 & 14.7 & 9.2 \\
\hline $\begin{array}{l}\text { Currently (last month) involved } \\
\text { in any kind of income- } \\
\text { generating activities (\%) }\end{array}$ & 13.1 & 8.0 & 14.3 & 9.0 & 10.1 & 13.1 & 10.8 & 12.6 & 11.1 & \\
\hline Saving for the future (\%) & 27.9 & 19.5 & 19.5 & 23.1 & $16.6 * * *$ & 35.3 & 22.3 & 23.4 & 22.5 & \\
\hline $\mathrm{N}$ & 750 & 749 & 747 & 744 & 2,050 & 940 & 332 & 109 & 2,990 & \\
\hline \multicolumn{11}{|l|}{ Main occupation } \\
\hline Tailor (\%) & 48.1 & 34.2 & 56.5 & 44.2 & 41.0 & 57.1 & 49.7 & 40.4 & 47.4 & \\
\hline Pottery/weaving (\%) & 22.5 & 13.9 & 10.1 & 12.6 & 11.7 & 20.0 & 15.4 & 13.8 & 15.0 & \\
\hline Teacher/private tutor (\%) & 7.8 & 12.7 & 8.0 & 6.3 & 10.2 & 5.7 & 6.6 & 13.8 & 8.4 & \\
\hline Mean weekly working hours & 14 & 14 & 11 & 12 & 12 & 14 & 12 & 16 & 13 & \\
\hline Mean monthly income BDT & 1,143 & 1,394 & 732 & 1,139 & 940 & 1,240 & 911 & 1,507 & 1,059 & \\
\hline $\mathrm{N}$ & 129 & 79 & 138 & 95 & 266 & 175 & 332 & 109 & 441 & \\
\hline
\end{tabular}

$* * * p<.001, * * p<.01, * p<.05$

aPercentages were calculated from BDHS household survey 2014 by selecting girls aged 12-19 residing in rural areas. 


\section{Discussion}

In the course of assessing baseline characteristics we note several findings that may also inform program strategies and are worth considering in the design of interventions.

- Schooling is universal and years of education average more than 7 , yet learning achievements remain low, particularly in the acquisition of the English language (41.9\%) and numeracy skills (only $37.5 \%$ did subtraction correctly, and other questions were lower still). Skill-building approaches will have to be designed assuming a low level of literacy, and basic literacy and numeracy may have to be a part of the skill-building curriculum.

- Marriage remains early (20.8\% of girls $12-19$ years are married) and is associated with high levels of demand for dowry (58.6\%) by grooms. Despite the considerable campaigns to raise awareness about child marriage and the illegality of dowry, the practices persist. Efforts at changing community norms may have to address norms around attitudes toward early marriage and acceptance of dowry.

- While we do not find reports of sexual activity before marriage, as a result of early marriage half of all married girls have had a pregnancy. Although the practice of effective contraception seems to be common $(67.7 \%$ of those married and not pregnant were current contractive users), it begins only after a first birth.

- Workforce participation is low-only $14.7 \%$ of adolescent respondents had ever worked, because opportunities are limited.

Study communities were randomized into three intervention and one control arm. The baseline data suggest that the randomization was effective in achieving balance across arms. There are no significant differences across study arms on most of the indicators of interest.

There are surprising differences between the two districts:

- $\quad$ Although Bogura is wealthier than Jamalpur as reflected in possession and characteristics of household living conditions, marriage rates are higher in Bogura than in Jamalpur and fewer girls are in school.

- While Jamalpur has higher proportions of girls who are currently in school, parental education in Jamalpur is considerably lower than in Bogura.

- $\quad$ Similarly, average number of siblings reported by adolescents suggest that Bogura has lower fertility than Jamalpur.

- Workforce participation is lower in Bogura compared to Jamalpur.

The baseline survey confirmed most of what we would have expected based on recent adolescent surveys conducted among girls of this age group in rural Bangladesh. Marriage is recognized as a major driver of school discontinuation even though most girls attend school until they marry. This generation of adolescents has benefited from education opportunities that eluded most of their parents.

The two districts are contiguous and share many similar characteristics. In addition to being overwhelmingly Muslim, there is also relatively little cultural diversity. The difference in terms of lower child marriage in Jamalpur relative to Bogura, which is wealthier, is striking. It is likely that the somewhat higher opportunity for earning income and employment explains this difference. Knowledge about reproductive health is consistently lower in Bogura relative to Jamalpur.

Based on the similarity of the profile of adolescents in these districts and the BALIKA intervention districts in southern Bangladesh, and the success of BALIKA in improving a range of outcomes in positive ways, we expect that interventions focusing on building skills that expand opportunities and offer alternative pathways so that girls are perceived as assets rather than liabilities in their communities have the potential for improving well-being. Offering opportunities to build skills and social assets can delay marriage, improve school continuation, increase reproductive health knowledge, and change gender-inequitable attitudes and norms. 


\section{References}

Amin, S., J. Ahmed, J. Saha, M. Hossain, and E. Haque.

2016. "Delaying child marriage through community-based skills-development programs for girls: Results from a randomized controlled study in rural Bangladesh." New York and Dhaka, Bangladesh: Population Council.

Bangladesh Bureau of Statistics (BBS) and United Nations Children's Fund (UNICEF). 2015. Multiple Indicator Cluster Survey 2012-2013 Progotir Patheyh. https://www.unicef. org/bangladesh/MICS_Final_21062015_Low.pdf.

Kalamar, A.M., S. Lee-Rife, and M.J. Hindin. 2016. "Interventions to prevent child marriage among young people in lowand middle-income countries: A systematic review of the published and gray literature," Journal of Adolescent Health 59(3): S16-S21. doi: 10.1016/j.jadohealth.2016.06.015.

Minnesota Population Center. 2018. Integrated Public Use Microdata Series, International: Version 7.0. Minneapolis: University of Minnesota.

National Institute of Population Research and Training (NIPORT), Mitra and Associates, and ICF International. 2013. Bangladesh Demographic and Health Survey 2011. Dhaka, Bangladesh and Calverton, Maryland: NIPORT, Mitra and Associates, and ICF International.

PLAN International and Coram International. 2015. Getting the Evidence: Asia Child Marriage Initiative-Summary Report. https://www.plancanada.ca/file/planv4_files/ biaag/Getting-the-Evidence_Asia-Child-Marriage_summary. pdf. Bangkok, Thailand.

Rutterford, C., A. Copas, and S. Eldridge. 2015. "Methods for sample size determination in cluster randomized trials," International Journal of Epidemiology 44(3): 1051-1067.

White, S.C. 2017. "Patriarchal investments: Marriage, dowry and the political economy of development in Bangladesh," Journal of Contemporary Asia 47(2): 247-272. 